\begin{tabular}{|c|c|}
\hline Title & Comparative analysis of al uminum accumulation in leaves of three angiosperm species \\
\hline Author(s) & Maejima, Eriko; Hiradate, Syuntaro; Jansen, Steven; O saki, Mitsuru; W atanabe, Toshihiro \\
\hline Citation & $\begin{array}{l}\text { Botany - Botanique, 92(5), 327-331 } \\
\text { https://doi.org/10.1139/cjb-2013-0298 }\end{array}$ \\
\hline Issue Date & 2014.05 \\
\hline Doc URL & http:/hdl.handle.net/2115/56550 \\
\hline Type & article (author version) \\
\hline File Information & HUSCAP用.pdf \\
\hline
\end{tabular}

Instructions for use 


\section{Comparative analysis of aluminum accumulation in leaves of three angiosperm species}

Eriko Maejima: Research Faculty of Agriculture, Hokkaido University, Kita-9, Nishi-9, Kitaku, Sapporo 060-8589, Japan (ericom@ @ chem.agr.hokudai.ac.jp)

Syuntaro Hiradate: National Institute for Agro-Environmental Sciences (NIAES), 3-1-3 Kan-nondai, Tsukuba 305-8604, Japan (hiradate@ affrc.go.jp)

Steven Jansen: Institute of Systematic Botany and Ecology, Ulm University, Albert-Einstein-Allee 11, D-89081 Ulm, Germany (steven.jansen@ uni-ulm.de)

Mitsuru Osaki: Research Faculty of Agriculture, Hokkaido University, Kita-9, Nishi-9, Kitaku, Sapporo 060-8589, Japan (mosaki@ chem.agr.hokudai.ac.jp)

Toshihiro Watanabe: Research Faculty of Agriculture, Hokkaido University, Kita-9, Nishi-9, Kitaku, Sapporo 060-8589, Japan (nabe @ chem.agr.hokudai.ac.jp)

Corresponding author: Toshihiro Watanabe; Research Faculty of Agriculture, Hokkaido University, Kita-9, Nishi-9, Kitaku, Sapporo 060-8589, Japan; +81-11-706-2498 (Tel \& Fax), nabe@ chem.agr.hokudai.ac.jp 
Abstract: Aluminum (Al) accumulators are widely distributed in the plant kingdom but phylogenetic implications of internal Al detoxification mechanisms are not well understood. We investigated differences in the characteristics of $\mathrm{Al}$ accumulation (i.e., accumulation potential, chemical form, and localization) in three woody $\mathrm{Al}$ accumulators, Symplocos chinensis (Symplocaceae, Ericales), Melastoma malabathricum, and Tibouchina urvilleana (both Melastomataceae, Myrtales). The order of $\mathrm{Al}$ accumulation potential under hydroponic conditions was $S$. chinensis $\approx M$. malabathricum $>T$. urvilleana. Oxalate was at least partly involved in the internal $\mathrm{Al}$ detoxification mechanisms in leaves of all three $\mathrm{Al}$ accumulators, based on a correlation analysis between $\mathrm{Al}$ and organic acid in water and $0.02 \mathrm{M} \mathrm{HCl}$ extracts and the ${ }^{27} \mathrm{Al}$ nuclear magnetic resonance spectra of intact leaves. However, the $\mathrm{Al}$ forms in the leaves were not simple Al-ligand complexes in a specific cell structure. Al localization in leaf sections differed among the three species. Extremely high levels of $\mathrm{Al}$ were found in trichomes of the lower epidermis in leaves of T. urvilleana. These data illustrate that woody $\mathrm{Al}$ accumulating angiosperms have independently developed various internal $\mathrm{Al}$ tolerance mechanisms in which oxalate plays a significant role.

Key words: Auminum accumulators, Melastoma malabathricum L., oxalate, Symplocos chinensis (Lour.) Druce var. leucocarpa (Nakai) Ohwi f., Tibouchina urvilleana Cogn., trichomes 


\section{Introduction}

Acid soils occupy approximately $30 \%$ of the world's ice-free land area (von Uexküll and Mutert, 1995). Owing to the toxic effects of $\mathrm{Al}$, acid soils with high levels of soluble $\mathrm{Al}$ restrict plant growth (Foy et al., 1978; Kochian et al., 2004). Al tolerance is generally interpreted as the ability to exclude Al. Exudation of organic acids from the roots is considered as one of the most important strategies by which Al is excluded (Kochian et al., 2004). In contrast, some plant species developed internal Al inactivation mechanisms to avoid Al toxicity. Of these, plant species with $\mathrm{Al}$ levels of at least $1000 \mathrm{mg} \mathrm{kg}^{-1}$ in their leaves or shoots are defined as Al accumulators (Chenery, 1948). Metali et al. (2012), however, argue for a higher threshold of 2.3 to $3.9 \mathrm{mg} \mathrm{Al} \mathrm{g}^{-1}$ leaf dry mass for distinguishing $\mathrm{Al}$ accumulators from non-accumulators for tropical plants.

$\mathrm{Al}$ accumulators have developed mechanisms to detoxify $\mathrm{Al}$ in their tissues by forming stable complexes with organic or inorganic ligands. For example, Al-citrate complexes are formed in leaves of Hydrangea macrophylla (Ma et al., 1997a). The formation of Al-Si complexes in leaves of Faramea marginata has also been suggested (Britez et al., 2002). Isolating Al from the sites that are sensitive to $\mathrm{Al}$ (especially the cytoplasm) is another important strategy to avoid Al toxicity in plant tissues. High levels of $\mathrm{Al}$ accumulate in vacuoles in buckwheat leaves (Shen et al., 2002) and epidermal cell walls in leaves of Melastoma malabathricum 
(Watanabe et al., 1998). There are also details for Camellia (tea plants) and Hydrangea macrophylla; see for instance the nice review by Brunner and Sperisen (2013).

The phylogenetic distribution of Al accumulators has been studied by several researchers. Jansen et al. (2002) comprehensively analyzed the data in the literature, and applied recent molecular phylogenies to evaluate the systematic and phylogenetic implications of the hyperaccumulation characteristic. They found that $\mathrm{Al}$ accumulators are mainly eudicots, and are particularly common in basal, woody branches of fairly advanced groups, such as rosids (Myrtales, Malpighiales, Oxalidales) and asterids (Cornales, Ericales, Gentianales, Aquifoliales), but the characteristic has probably been lost in more derived, herbaceous taxa (Jansen et al., 2002).

Although $\mathrm{Al}$ accumulators are found in various vascular plant taxa, little attention has been paid to physiological, chemical, and anatomical differences of $\mathrm{Al}$ accumulation in leaves of various accumulating species. Therefore, this study aims to characterize $\mathrm{Al}$ accumulation (i.e., accumulation potential, chemical form, and localization) in representative $\mathrm{Al}$ accumulators of the orders Myrtales and Ericales, both of which contains many Al accumulator species (Jansen et al. 2002, 2004). M. malabathricum (Melastomataceae), which represents a well-studied $\mathrm{Al}$ accumulator, was used as control species. The diversity of $\mathrm{Al}$ hyperaccumulation characteristics are discussed by comprehensive analysis of the results 
from this study and literature.

\section{Materials and Methods}

Estimating Al-accumulation potential in different Al accumulators

Uniform cuttings from mature plants of M. malabathricum L. (Melastomataceae) and Tibouchina urvilleana Cogn. (Melastomataceae) were rooted and precultured in a $40-\mathrm{L}$ container containing an Al-free standard nutrient solution that was aerated constantly for 1 month in a glasshouse at Hokkaido University under natural conditions (13-15 h photoperiod and a day:night temperature of $25-28: 18-22^{\circ} \mathrm{C}$ ). Plants of Symplocos chinensis (Lour.) Druce var. leucocarpa (Nakai) Ohwi f. pilosa (Nakai) Ohwi (Symplocaceae) were purchased from a garden center. The roots were carefully washed with tap water to remove adhering soils. Subsequently, the plants were transferred to a continuously aerated 40-L container containing a standard nutrient solution for hydroponic preculture, and grown for 1 month. The standard nutrient solution contained $0.54 \mathrm{mM} \mathrm{N}\left(\mathrm{NH}_{4} \mathrm{NO}_{3}\right), 0.16 \mathrm{mM} \mathrm{P}\left(\mathrm{NaH}_{2} \mathrm{PO}_{4} \cdot 2 \mathrm{H}_{2} \mathrm{O}\right), 0.15 \mathrm{mM} \mathrm{K}$ $\left(\mathrm{K}_{2} \mathrm{SO}_{4}: \mathrm{KCl}=1: 1\right), 0.25 \mathrm{mM} \mathrm{Ca}\left(\mathrm{CaCl}_{2} \cdot 2 \mathrm{H}_{2} \mathrm{O}\right), 0.16 \mathrm{mM} \mathrm{Mg}\left(\mathrm{MgSO}_{4} \cdot 7 \mathrm{H}_{2} \mathrm{O}\right), 35.8 \mu \mathrm{M} \mathrm{Fe}$ $\left(\mathrm{FeSO}_{4} \cdot 7 \mathrm{H}_{2} \mathrm{O}\right), 9.1 \mu \mathrm{M} \mathrm{Mn}\left(\mathrm{MnSO}_{4} \cdot 4 \mathrm{H}_{2} \mathrm{O}\right), 46.3 \mu \mathrm{M} \mathrm{B}\left(\mathrm{H}_{3} \mathrm{BO}_{3}\right), 3.1 \mu \mathrm{M} \mathrm{Zn}\left(\mathrm{ZnSO}_{4} \cdot 7 \mathrm{H}_{2} \mathrm{O}\right)$, $0.16 \mu \mathrm{M} \mathrm{Cu}\left(\mathrm{CuSO}_{4} \cdot 5 \mathrm{H}_{2} \mathrm{O}\right)$, and $0.05 \mu \mathrm{M} \mathrm{Mo}\left(\left(\mathrm{NH}_{4}\right)_{6} \mathrm{Mo}_{7} \mathrm{O}_{24} \cdot 4 \mathrm{H}_{2} \mathrm{O}\right)$; total $\mathrm{SO}_{4}=0.21 \mathrm{mM}$. After preculturing, the plants were transferred to a phosphorus free standard nutrient solution 
with $0.5 \mathrm{mM} \mathrm{AlCl}_{3}\left(\left\{\mathrm{Al}^{3+}\right\}=0.154 \mathrm{mM}\right.$, calculated by GEOCHEM-EZ (Shaff et al., 2010)), and cultivated for 3 months. The solution was adjusted daily to a $\mathrm{pH}$ of 4.0. After the $\mathrm{Al}$ treatment, the plants were sampled, washed with deionized water, and cut to separate roots and leaves. The fresh samples were dried at $75^{\circ} \mathrm{C}$ for 4 days, weighed and ground. Ground samples were digested with $\mathrm{HNO}_{3}-\mathrm{H}_{2} \mathrm{O}_{2}$, and mineral concentrations were determined by inductively coupled plasma mass spectrophotometry (ELAN DRC-e, Perkin Elmer, Waltham, MA, USA).

\section{Identifying the chemical form of Al in leaves of Al accumulators}

We first examined the correlation between $\mathrm{Al}$ and organic acid concentrations in leaves. Leaves at different stages of development (young, mature, and old) were sampled individually from plants of three $\mathrm{Al}$ accumulators grown in a standard nutrient solution with $0.5 \mathrm{mM} \mathrm{Al}$ for 2 months, as described above. Fresh leaves were ground on ice using a mortar and pestle with $1 \mathrm{~mL}$ of water or $0.02 \mathrm{M} \mathrm{HCl}($ sample $(\mathrm{mg})$ :solution $(\mu \mathrm{L})=1: 10)$. Water and $0.02 \mathrm{M} \mathrm{HCl}$ extracts were filtered through a membrane filter (pore size $=0.45 \mu \mathrm{m}$ ), and organic acid and Al concentrations were determined by capillary electrophoresis (Quanta 4000CE, Waters, Milford, MA, USA; Watanabe et al., 1998) and inductively coupled plasma atomic emission spectroscopy (ICPS-7000, Shimadzu, Kyoto, Japan), respectively. Furthermore, liquid-state 
${ }^{27} \mathrm{Al}$ nuclear magnetic resonance (NMR) was used to determine the $\mathrm{Al}$ form in the leaves. Fresh leaves of three $\mathrm{Al}$ accumulators were individually placed in a NMR tube $(10 \mathrm{~mm}$ diameter). The Al concentrations in leaves of $S$. chinensis, M. malabathricum, and $T$. urvilleana used for ${ }^{27} \mathrm{Al}$ NMR analysis were 6890, 7920, and $8680 \mathrm{mg} \mathrm{kg}^{-1} \mathrm{DW}$, respectively. The ${ }^{27} \mathrm{Al}$ NMR spectrum was recorded at 156.3 MHz (JNM- $\alpha 600$ spectrometer; JEOL, Tokyo, Japan). The parameters used were as follows: frequency range, $62.5 \mathrm{kHz}$; data point, $131 \mathrm{k}$; and acquisition time, $0.6 \mathrm{~s}$. An aluminum chloride solution $\left(1 \mathrm{mM} \mathrm{AlCl}_{3}\right.$ in $\left.0.1 \mathrm{M} \mathrm{HCl}\right)$ was used as an external reference for calibration of the chemical shift ( $0 \mathrm{ppm})$. The spectrum of the leaves was compared with that of a mixture of $\mathrm{AlCl}_{3}(1 \mathrm{mM})$ and oxalate $(1$ or $3 \mathrm{mM})$, malate $(2 \mathrm{mM})$, or citrate $(2 \mathrm{mM})(\mathrm{pH} 4.0)$, which were added to a $5-\mathrm{mm}$ tube and subjected to ${ }^{27} \mathrm{Al}$ NMR analysis using the following parameters: frequency range, $62.5 \mathrm{kHz}$; data point, 33 $\mathrm{k}$; and acquisition time, $0.52 \mathrm{~s}$.

\section{Localization of aluminum in leaves of Al accumulators}

Mature leaves of the three $\mathrm{Al}$ accumulators grown in a standard nutrient solution with $0.5 \mathrm{mM}$ $\mathrm{Al}$ as described above were sampled to examine Al localization. After washing with deionized water, the leaves were sectioned $(20 \mu \mathrm{m}$ thickness) with a cryo-microtome (CM-3050S, Leica Biosystems, Wetzlar, Germany). After sectioning, the transverse sections were stained on a 
glass slide with pyrocatechol violet (PCV) according to the method of Watanabe et al. (1998). In brief, the sections were stained with $0.02 \%(\mathrm{w} / \mathrm{v}) \mathrm{PCV}$ and $2.5 \%(\mathrm{w} / \mathrm{v})$ hexamine- $\mathrm{NH}_{4} \mathrm{OH}$ buffer ( $\mathrm{pH}$ 6.2) for $15 \mathrm{~min}$, washed with $2.5 \%$ hexamine- $\mathrm{NH}_{4} \mathrm{OH}$ buffer $(\mathrm{pH}$ 6.2), and observed under a light microscope (BX51, Olympus, Tokyo, Japan).

\section{Results}

\section{Al accumulation}

Al concentration in leaves of $S$. chinensis and M. malabathricum grown for 3 months in a nutrient solution with $0.5 \mathrm{mM} \mathrm{Al}$ exceeded $8000 \mathrm{mg} \mathrm{kg}^{-1}$, whereas that in T. urvilleana was less than half that of these two species (Table 1).

Al and organic acid concentrations in water and $0.02 \mathrm{M} \mathrm{HCl}$ extracts

Young, mature, and old leaves were separately extracted with water or $0.02 \mathrm{M} \mathrm{HCl}$, and $\mathrm{Al}$ and organic acid concentrations in both extracts were determined (Table 2). A significant positive correlation was observed between $\mathrm{Al}$ and oxalate concentrations in water and $0.02 \mathrm{M}$ $\mathrm{HCl}$ extracts of $S$. chinensis and $M$. malabathricum, respectively (Table 3). No significant correlation was observed between $\mathrm{Al}$ and organic acid concentrations in T. urvilleana, and the molar ratios of oxalate to $\mathrm{Al}$ in both extracts were low (Tables 2 and 3 ). 
${ }^{27}$ Al NMR

When comparing the ${ }^{27} \mathrm{Al} \mathrm{NMR} \mathrm{spectrum} \mathrm{of} \mathrm{intact} \mathrm{leaves} \mathrm{with} \mathrm{a} \mathrm{mixture} \mathrm{of} \mathrm{Al}$ and organic acid, the resonance peaks in M. malabathricum corresponded almost to those obtained for the Al-oxalate mixture (Fig. 1). The chemical shifts of the minor downfield peaks corresponded to those of the mixture of Al-oxalate, but shifted greatly downfield in both $S$. chinensis and $T$. urvilleana (Fig. 1).

\section{Al localization in leaves}

Staining with PCV yielded a blue color by generating a chelating complex with Al. PCV staining of the leaf transverse section indicated that the distribution of $\mathrm{Al}$ in S. chinensis and M. malabathricum was similar; high levels of Al were found in epidermal cells but not in mesophyll cells (Fig. 2A and 2B). In T. urvilleana, Al localized in the thick lower epidermis, particularly in trichomes (Fig. 2C).

\section{Discussion}

$\mathrm{Al}$ accumulators are defined as plants containing more than $1000 \mathrm{mg} \mathrm{Al} \mathrm{kg}^{-1} \mathrm{DW}$ in their leaves or shoots (Chenery, 1948). However, some Al accumulators adapted to strongly acid 
soils, particularly in the tropics, may contain more than $5000 \mathrm{mg} \mathrm{Al} \mathrm{kg}^{-1}$ in their leaves or shoots (de Medeiros and Haridasan, 1985; Masunaga et al., 1998; Osaki et al., 2003). Strong Al accumulators are often observed in the genus Symplocos (Watanabe et al., 2007), including S. chinensis used in this study. S. spicata was reported to contain more than $72000 \mathrm{mg} \mathrm{Al} \mathrm{kg}{ }^{-1}$ in its leaves by von Faber (1925). M. malabathricum is also a strong Al accumulator containing $\geq 10000 \mathrm{mg} \mathrm{Al} \mathrm{kg}^{-1}$ in leaves.

Among the three Al accumulators examined, S. chinensis and M. malabathricum showed comparably higher $\mathrm{Al}$ accumulation in leaves than $T$. urvilleana (Table 1). This result indicates that characteristics of $\mathrm{Al}$ accumulation are quantitatively different between $M$. malabathricum and T. urvilleana, despite the fact that Tibouchina and Melastoma belong to the Melastomataceae family and are therefore phylogenetically closely related.

Formation of stable complexes with organic and inorganic ligands is an important mechanism for internal $\mathrm{Al}$ detoxification in $\mathrm{Al}$ accumulators (Watanabe and Osaki, 2002). Organic acids are common ligands for $\mathrm{Al}$ in many $\mathrm{Al}$ accumulators. In our previous studies, for example, we showed that soluble $\mathrm{Al}$ forms in leaves and roots of $M$. malabathricum are Al-oxalate complexes and inorganic monomeric Al ions (Watanabe et al., 1998; 2005). To elucidate the species-specific formation of $\mathrm{Al}$ complexes in leaves, the relationship between $\mathrm{Al}$ and organic acid concentrations was investigated. Only oxalate showed a comparable concentration to Al 
in all three accumulators (Table 2), and a significant positive correlation was found between $\mathrm{Al}$ and oxalate concentrations in water and $0.02 \mathrm{M} \mathrm{HCl}$ extracts of $S$. chinensis and $M$. malabathricum, respectively (Table 3). The fact that we found no significant correlation for the water extract of $M$. malabathricum may be because of a higher concentration of free oxalate in the extract (Table 2). In contrast, oxalate concentration in both extracts was low in comparison with $\mathrm{Al}$ concentration, and no significant correlation was observed between $\mathrm{Al}$ and organic acid concentrations in T. urvilleana (Tables 2 and 3). These results imply that the primary forms of soluble $\mathrm{Al}$ are Al-oxalate complexes in S. chinensis and M. malabathricum, but not in T. urvilleana.

Although determining the correlation between $\mathrm{Al}$ and possible ligands is an effective method to estimate $\mathrm{Al}$ forms in a plant, additional method(s) such as the ${ }^{27} \mathrm{Al}$ NMR technique, which can non-destructively estimate Al species in intact leaves, must be employed because it is possible that the extraction process changes the forms of Al. The chemical shift of each peak in intact leaves of M. malabathricum corresponded fairly well to the peaks of the Al-oxalate mixture (Fig. 1), suggesting that the primary forms of soluble $\mathrm{Al}$ in leaves of $M$. malabathricum are Al-oxalate complexes and inorganic monomeric $\mathrm{Al}$ as shown in our previous report (Watanabe et al., 1998). Likewise, the chemical shifts of the minor downfield peaks corresponded to those of the mixture of Al-oxalate in both S. chinensis and T. urvilleana 
but shifted greatly downfield (Fig. 1). This result suggests that the $\mathrm{pH}$ and/or ion composition in the environment, where Al-oxalate complexes exist in leaves of $S$. chinensis and $T$. urvilleana, could differ substantially from those in the standard solution.

The ${ }^{27} \mathrm{Al}$ NMR spectrum of intact leaves of all three species showed octahedral Al-oxalate complexes with empty coordination positions (coordinated with $\mathrm{H}_{2} \mathrm{O}$ or $\mathrm{OH}^{-}$, Hiradate 2004) (Fig. 1). If oxalate concentration is high enough to bind to $\mathrm{Al}$ at cytosolic $\mathrm{pH}(\mathrm{pH} 7.0-7.5)$, the major resonance peak must appear at around $18 \mathrm{ppm}\left(\mathrm{Al}-(\text { oxalate })_{3}\right)$. Even if the oxalate concentration is not high enough, proteins and phospholipids could easily bind to these $\mathrm{Al}$ complexes with empty coordination positions at cytosolic $\mathrm{pH}$. Thus, these results suggest that Al may primarily occur at acidic sites, such as vacuoles, in leaves of these Al accumulators. The major resonance peak in leaf samples at approximately $0 \mathrm{ppm}$, presumably mainly derived from inorganic monomeric $\mathrm{Al}$ species, also indicates $\mathrm{Al}$ accumulation in acidic sites, particularly in T. urvilleana (Fig. 1). A comparison of the ${ }^{27} \mathrm{Al}$ NMR spectrum of the isolated protoplasts and vacuoles with that of intact leaves is necessary for more exact speciation of $\mathrm{Al}$ in leaves. Moreover, an $\mathrm{Al}$ complex composed of multiple inorganic and/or organic ligands as well as the coexistence of different Al-ligand complexes in leaf tissues should also be considered.

Al localization in leaves may also be related to mechanisms of Al tolerance because 
sequestration of $\mathrm{Al}$ from sensitive tissues is also important for $\mathrm{Al}$ accumulators. In $S$. chinensis and M. malabathricum, high levels of $\mathrm{Al}$ accumulation were observed in epidermal cells but not in mesophyll cells, which are responsible for photosynthesis (Fig. 2A and 2B). Al localizes in leaf epidermal cells of many $\mathrm{Al}$ accumulators including Camellia sinensis (Tolrà et al., 2011), Faramea marginata (Britez et al., 2002), and Richeria grandis (Cuenca et al., 1991). Meanwhile, Al localized in the thick lower epidermis but not in upper epidermis of $T$. urvilleana, particularly in trichomes (Fig. 2C). In addition to $\mathrm{Al}$, it has been reported that some plants also accumulate Mn (e.g., sunflower; Blamey et al., 1986, pumpkin; Iwasaki and Matsuura 1999), Cd (e.g., Indian mustard; Salt et al., 1995), or Ni (e.g., Alyssum L., Broadhurst et al., 2009) in trichomes. Choi et al. (2001) found large crystals formed on head cells of trichomes contain high concentrations of $\mathrm{Cd}$ and $\mathrm{Ca}$. They expected that these crystals were composed of Ca-oxalate, in which $\mathrm{Cd}$ was embedded.

In conclusion, our results suggest that oxalate is commonly used as a ligand for a portion of $\mathrm{Al}$ in leaves of three woody $\mathrm{Al}$ accumulators, whereas other $\mathrm{Al}$ forms could be dominant, particularly in T. urvilleana. Oxalate is a major organic ligand for detoxification of $\mathrm{Al}$ in many Al accumulators, such as Camellia sinensis (Theaceae, Ericales, Morita et al., 2008) and Fagopyrum esculentum (Polygonaceae, Caryophyllales, Ma et al., 1997b). Oxalate has often been regarded as an end product that is not further metabolized or only slowly metabolized. 
Many $\mathrm{Al}$ accumulators may effectively use oxalate, which is less metabolically important, for internal $\mathrm{Al}$ detoxification, irrespective of the plant phylogeny. However, because the results of the ${ }^{27} \mathrm{Al}$ NMR analysis using intact leaves suggested that oxalate does not simply form a complex with $\mathrm{Al}$ in leaf cells, further investigations are necessary. Localization of $\mathrm{Al}$ in a leaf section was not similar between M. malabathricum and T. urvilleana, despite both being in the same family of Melastomataceae, suggesting that the phylogenetic effect is relatively small for tissue compartmentalization of $\mathrm{Al}$ in leaves. However, we investigated only three $\mathrm{Al}$ accumulators in this study. Because $\mathrm{Al}$ accumulators are widely distributed in vascular plants (Jansen et al., 2004; Watanabe et al., 2007; Metali et al. 2012), a more extensive survey is needed.

\section{Acknowledgments}

This study was supported financially by Grants-in-Aid for Scientific Research (No. 24580088) from the Japanese Society for the Promotion of Science (TW), a grant from the

Sapporo Agricultural Alumni Association (EM), and a grant from the Juniorprofessorenprogramm MWK (Baden-Wurttemberg) (SJ). 


\section{References}

Blamey, F.P.C., Joyce, D.C., Edwards, D.G., Asher, C.J. 1986. Role of trichomes in sunflower tolerance to manganese toxicity. Plant Soil. 91:171-80.

Britez, R.M., Watanabe, T., Jansen, S., Reissmann, C.B., and Osaki, M. 2002. The relationship between aluminium and silicon accumulation in leaves of Faramea marginata (Rubiaceae). New Phytol. 156: 437-444.

Broadhurst, C.L., Tappero, R,. Maugel, T., Erbe, E., Sparks, D., Chaney, R. 2009. Interaction of nickel and manganese in accumulation and localization in leaves of the $\mathrm{Ni}$ hyperaccumulators Alyssum murale and Alyssum corsicum. Plant Soil. 314: 35-48.

Brunner, I andSperisen, C. 2013. Aluminium exclusion and aluminium tolerance in woody plants. Front. Plant Sci. 4: 1-12.

Chenery, E.M. 1948. Aluminium in the plant world. Part I, general survey in dicotyledons. Kew Bull. 2: 173-183.

Choi, Y.E., Harada, E., Wada, M., Tsuboi, H., Morita, Y., Kusano, T., Sano, H. 2001. Detoxification of cadmium in tobacco plants: formation and active excretion of crystals containing cadmium and calcium through trichomes. Planta. 213: 45-50.

Cuenca, G., Herrera, R., and Merida, T. 1991. Distribution of aluminium in accumulator plants by X-ray microanalysis in Richeria grandis Vahl leaves from a cloud forest in 
Venezuela. Plant Cell Environ. 14: 437-441.

de Medeiros, R.A., and Haridasan, M. 1985. Seasonal variations in the foliar concentrations of nutrients in some aluminium accumulating and non-accumulating species of the cerrado region of central Brazil. Plant Soil 88: 433-436.

Foy, C.D., Chaney, R.L., and White, M.C. 1978. The physiology of metal toxicity in plants. Annu. Rev. Plant Physiol. 29: 511-566.

Hiradate, S. 2004. Speciation of aluminum in soil environments. Soil Science and Plant Nutrition 50: 303-314.

Iwasaki, K., and Matsumura, A. 1999. Effect of silicon on alleviation of manganese toxicity in pumpkin (Cucurbita moschata Duch cv. Shintosa). Soil Sci. Plant Nutr. 45: 909-20.

Jansen, S., Broadley, M.R., Robbrecht, E., and Smets, E. 2002. Aluminum hyperaccumulation in angiosperms: A review of its phylogenetic significance. Bot. Rev. 68(2): 235-269.

Jansen, S., Watanabe, T., Dessein, S., Robbrecht, E., and Smets, E. 2004. The evolution of aluminium accumulation in angiosperms. In The Evolution of Plant Physiology. From whole plant to ecosystems. Edited by A.R. Hemsley and I. Poole. Elsevier Academic Press, London pp. 467-479.

Kochian, L., Hoekenga, O.A., and Piñeros, M.A. 2004. How do crop plants tolerate acid soils? Mechanisms of aluminum tolerance and phosphorous efficiency. Annu. Rev. Plant Biol. 
55: 459-493.

Ma, J.F., Hiradate, S., Nomoto, K., Iwashita, T., and Matsumoto, H. 1997a. Internal detoxification mechanism of Al in hydrangea. Plant Physiol. 113: 1033-1039.

Ma, J.F., Zheng, S.J., Matsumoto, H., and Hiradate, S. 1997b. Detoxifying aluminium with buckwheat. Nature 390: 569-570.

Masunaga, T., Kubota, D., Hotta, M., and Wakatsuki, T. 1998. Mineral composition of leaves and bark in aluminum accumulators in a tropical rain forest in Indonesia. Soil Sci. Plant Nutr. 44: $347-358$.

Metali, F., Salim, K.A., and Burslem, D.F.R.P. 2012. Evidence of foliar aluminium accumulation in local, regional and global datasets of wild plants. New Phytol. 193(3): 637-649.

Morita, A., Yanagisawa, O., Takatsu, S., Maeda, S., and Hiradate, S. 2008. Mechanism for the detoxification of aluminum in roots of tea plant (Camellia sinensis (L.) Kuntze). Phytochem. 69: 147-153.

Osaki, M., Watanabe, T., Ishizawa, T., Nilnond, C., Nuyim, T., Shinano, T., Urayama, M., and Tuah, S.J. 2003. Nutritional characteristics of the leaves of native plants growing in adverse soils of humid tropical lowlands. Plant Food Human Nutr. 58: 93-115.

Salt, D.E., Prince, R.C., Pickering, I.J., Raskin, I. 1995. Mechanisms of cadmium mobility 
and accumulation in indian mustard. Plant Physiol. 109: 1427-33.

Shaff, J., Schultz, B., Craft, E., Clark, R., and Kochian, L. 2010. GEOCHEM-EZ: a chemical speciation program with greater power and flexibility. Plant and Soil 330(1): 207-214.

Shen, R., Ma, J.F., Kyo, M., and Iwashita, T. 2002. Compartmentation of aluminium in leaves of an Al-accumulator, Fagopyrum esculentum Moenoch. Planta 215: 394-398.

Tolrà, R., Vogel-Mikuš, K., Hajiboland, R., Kump, P., Pongrac, P., Kaulich, B., Gianoncelli, A., Babin, V., Barceló, J., Regvar, M., and Poschenrieder, C. 2011. Localization of aluminium in tea (Camellia sinensis) leaves using low energy X-ray fluorescence spectro-microscopy. J Plant Res 124(1): 165-172.

von Faber, V.F.C. 1925. Untersuchungen über die physiologie der javanische solfataren-pflanzen. Flora 118: 89-110.

von Uexküll, H.R., and Mutert, E. 1995. Global extent, development and economic impact of acid soils. Plant Soil 171: 1-15.

Watanabe, T., and Osaki, M. 2002. Mechanisms of adaptation to high aluminum condition in native plant species growing in acid soils: a review. Commun. Soil Sci. Plant Anal. 33: $1247-1260$.

Watanabe, T., Broadley, M.R., Jansen, S., White, P.J., Takada, J., Satake, K., Takamatsu, T., Tuah, S.J., and Osaki, M. 2007. Evolutionary control of leaf element composition in plants. 
New Phytol. 174: 516-523.

Watanabe, T., Misawa, S., and Osaki, M. 2005. Aluminum accumulation in the roots of Melastoma malabathricum, an aluminum-accumulating plant. Can. J. Bot. 83: 1518--1522.

Watanabe, T., Osaki, M., Yoshihara, T., and Tadano, T. 1998. Distribution and chemical speciation of aluminum in the $\mathrm{Al}$ accumulator plant, Melastoma malabathricum L. Plant Soil 201(2): 165-173. 


\section{Table captions}

Table 1. Total $\mathrm{Al}$ concentration $\left(\mathrm{mg} \mathrm{kg}^{-1}\right)$ in leaves of three $\mathrm{Al}$ accumulators grown in a standard nutrient solution with $0.5 \mathrm{mM} \mathrm{Al}$

Table 2. Average concentration $(\mathrm{mM})$ of $\mathrm{Al}$, oxalate, malate, and citrate in the extract of leaves

Table 3. Correlation coefficient between $\mathrm{Al}$ and each organic acid concentrations 


\section{Figure captions}

Fig. $1{ }^{27} \mathrm{Al}$ NMR spectra of the standard solution $\left(1 \mathrm{mM} \mathrm{AlCl} \mathrm{Al}_{3}+1 \mathrm{mM} / 3 \mathrm{mM}\right.$ oxalate, $\mathrm{pH}$

4.0) and the intact leaves of Symplocos chinensis, Tibouchina urvilleana, and Melastoma malabathricum grown in a nutrient solution containing $0.5 \mathrm{mM}$.

Fig. 2 Transverse sections of Symplocos chinensis (A), Tibouchina urvilleana (B), and Melastoma malabathricum (C) after pyrocatechol violet staining. Blue-colored tissues indicate localization of Al. Bar $=100 \mu \mathrm{m}$ 


\section{Table 1}

\begin{tabular}{ll}
\hline Symplocos chinensis & $8309 \pm 282$ \\
Tibouchina urvilleana & $3431 \pm 262$ \\
Melastoma malabathricum & $8540 \pm 1330$ \\
\hline
\end{tabular}

Values are means of 3 replicates \pm standard error 


\section{Table 2}

\begin{tabular}{|c|c|c|c|c|c|c|c|c|c|}
\hline \multirow[b]{2}{*}{ Water soluble } & \multirow[b]{2}{*}{ Symplocos chinensis } & \multicolumn{2}{|c|}{$\mathrm{Al}$} & \multicolumn{2}{|c|}{ Oxalate } & \multicolumn{2}{|c|}{ Malate } & \multicolumn{2}{|c|}{ Citrate } \\
\hline & & 2.84 & $(0.286)$ & 2.92 & $(0.310)$ & 0.348 & $(0.239)$ & 0.441 & $(0.738)$ \\
\hline \multirow[t]{2}{*}{$(n=8)$} & Tibouchina urvilleana & 1.00 & $(0.196)$ & 0.67 & $(0.451)$ & 0.233 & $(0.263)$ & 0.392 & $(0.753)$ \\
\hline & Melastoma malabathricum & 3.14 & $(0.166)$ & 6.49 & $(0.228)$ & 0.205 & $(0.483)$ & 0.744 & $(0.335)$ \\
\hline $0.02 \mathrm{M} \mathrm{HCl}$ soluble & Symplocos chinensis & 4.67 & $(0.156)$ & 7.44 & $(0.239)$ & 0.357 & $(0.599)$ & 0.381 & $(0.877)$ \\
\hline \multirow[t]{2}{*}{$(\mathrm{n}=8)$} & Tibouchina urvilleana & 2.14 & $(0.587)$ & 1.88 & $(0.502)$ & 0.211 & $(0.646)$ & 0.188 & $(0.548)$ \\
\hline & Melastoma malabathricum & 6.04 & $(0.153)$ & 23.11 & $(0.257)$ & 0.412 & $(0.303)$ & 1.874 & $(0.554)$ \\
\hline Water soluble / & Symplocos chinensis & 0.61 & & 0.39 & & 0.98 & & 1.16 & \\
\hline \multirow[t]{2}{*}{$0.02 \mathrm{M} \mathrm{HCl}$ soluble ${ }^{a}$} & Tibouchina urvilleana & 0.47 & & 0.35 & & 1.10 & & 2.08 & \\
\hline & Melastoma malabathricum & 0.52 & & 0.28 & & 0.50 & & 0.40 & \\
\hline
\end{tabular}

Values in brackets are coefficients of variation.

${ }^{a}$ Concentration of each component in the $w$ ater extract / that in the $0.02 \mathrm{M} \mathrm{HCl} \mathrm{extract}$ 
Table 3

\begin{tabular}{llcrr}
\hline & & Oxalate & Malate & Citrate \\
\hline Water soluble & Symplocos chinensis & $0.924^{* *}$ & 0.624 & 0.647 \\
& Tibouchina urvilleana & 0.531 & 0.277 & -0.007 \\
& Melastoma malabathricum & -0.168 & -0.552 & -0.143 \\
& & & \\
$0.02 \mathrm{M} \mathrm{HCl}$ soluble & Symplocos chinensis & 0.364 & -0.236 & 0.397 \\
& Tibouchina urvilleana & 0.659 & -0.080 & 0.508 \\
& Melastoma malabathricum & $0.858^{*}$ & 0.157 & 0.590 \\
\hline
\end{tabular}

${ }^{* *}$ and ${ }^{*}$, significant at $P<0.01$ and 0.05 , respectively. 
Fig. 1

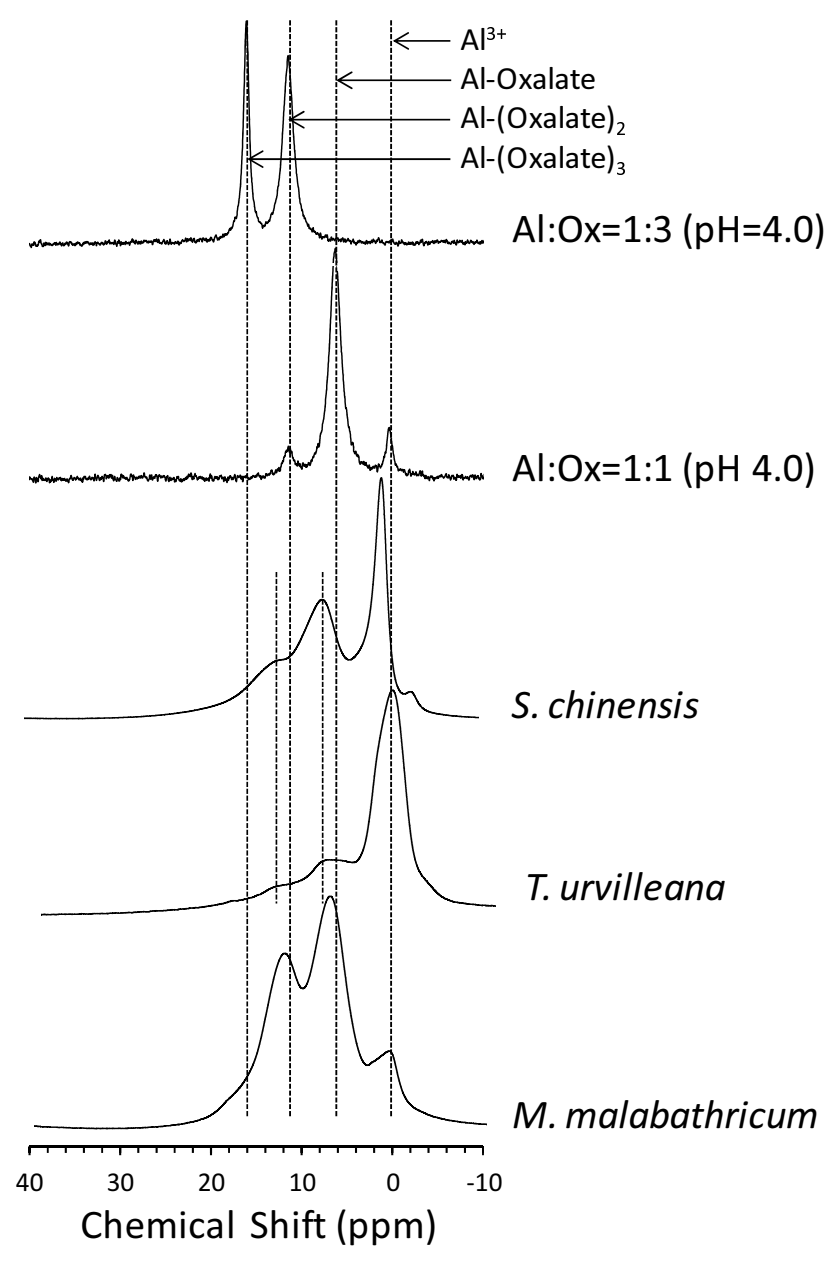


Fig. 2
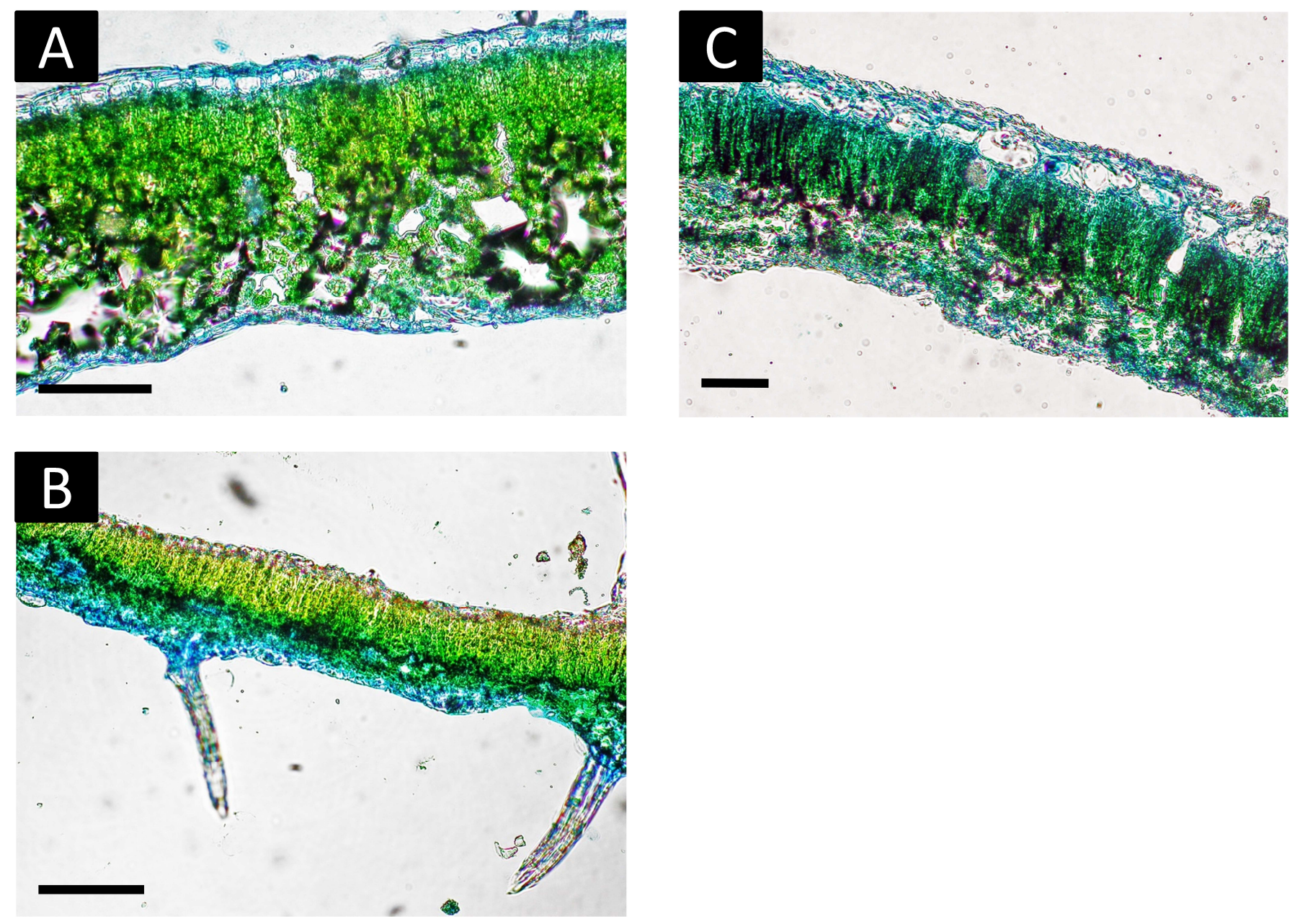